\title{
The borders, they are a-changin'! The emergence of socio-digital borders in the EU
}

\author{
Magdalena König \\ Maastricht University, Netherlands
}

Published on 31 Mar 2016 | DOI: 10.14763/2016.1.403

\begin{abstract}
Relying on big data, modern surveillance becomes increasingly influential in determining societal power relations. Lyon argues that modern surveillance always categorises people entailing social effects, what he conceptualises as social sorting. This paper assesses if patterns of social sorting can be found in the EU surveillance systems for migration Schengen Information System (SIS), Visa Information System (VIS) and EUROpean DACtylographic comparison system (EURODAC), which are planned to be merged in order to ensure maximum efficiency in surveillance. To do so, the paper analyses relevant documents referring to SIS, VIS and EURODAC. These systems have assumed the traditional border function of deciding on societal inclusion and exclusion. I argue that, to some extent, socio-digital borders are drawn along the categories established through social sorting. The paper exemplifies how social sorting relying on big data may be a disempowering surveillance practice.
\end{abstract}

Keywords: Social sorting, Borders, Big data

\section{Article information}

Received: 18 Dec 2015 Reviewed: 16 Feb 2016 Published: 31 Mar 2016

Licence: Creative Commons Attribution 3.0 Germany

Competing interests: The author has declared that no competing interests exist that have influenced the text.

URL:

http://policyreview.info/articles/analysis/borders-they-are-changin-emergence-socio-digital-borders-e u

Citation: König, M. (2016). The borders, they are a-changin'! The emergence of socio-digital borders in the EU. Internet Policy Review, 5(1). https://doi.org/10.14763/2016.1.403

This paper is part of 'Big data: big power shifts?', a Special issue of Internet Policy Review, supported by the Vodafone Institute for Society and Communications.

\section{INTRODUCTION}

When the European Union (EU) abolished internal border controls within the Schengen area in the 1990s, political leaders saw a need to preempt the loss of control over non-EU citizens. To

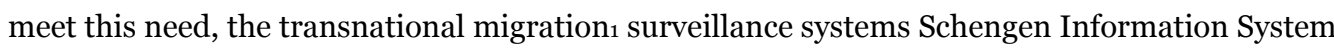


(SIS), Visa Information System (VIS) and EURODAC have been charged with collecting data concerning third-country nationals entering the EU.

Lyon (2003) assesses that transnational surveillance systems increasingly show patterns of social sorting, that is obtaining data to classify people into risk categories such as citizens, migrants or potential criminals. This may lead to establishing or strengthening social differences among the classified individuals. Starting out from Lyon's assumption that every form of modern surveillance entails social sorting, this paper assesses in how far and with what consequences EU databases use such classification. While Lyon (2003) focuses on Northern American surveillance, this paper seeks to complement his research focusing on EU surveillance systems.

I claim that SIS, VIS and EURODAC exhibit social sorting and affect the political power of the classified groups both positively and negatively. This changes the notion of borders since the power to divide into societal in- and outsiders is shifted from territorial towards socio-digital borders. To some extent, borders are redrawn along the social categories reinforcing already existing power relations. As the title suggests, the borders in Europe are changing through big data surveillance. This paper thus shows how social sorting relying on big data may represent a disempowering form of surveillance.

I firstly show how modern surveillance, big data, social sorting and power are linked. Subsequently, I explain the design of SIS, VIS and EURODAC and analyse the systems according to the criteria of social sorting identified in section 2. The paper finishes with a discussion of socio-digital borders and power effects of big data surveillance.

\section{SOCIAL SORTING: SURVEILLANCE THAT (DIS)EMPOWERS}

Large-scale generic surveillance has recently become criticised for suspicion without prior evidence (Weidemann, 2014). To explain social problems that surveillance may entail, I define the features of modern surveillance relying on big data.

Jenkins (2012) identifies three characteristics of modern surveillance: surveillance serves specific purposes. It is one-directional, with the watcher observing a subject who is not empowered to observe the watcher in turn. Finally, surveillance is increasingly impersonal and remote. While traditionally aimed at specific persons, modern surveillance tends towards generic data storage (pp. 162-163). Bendrath (2014) adds the element of information sharing which is increasingly important since it enables data to become mobile (p. 21). Following 9/11,2 Lyon (2014) perceives a change in surveillance practices. It is particularly the use of big data that has changed surveillance from Foucauldian discipline to a control tool (p. 2). Big data intensifies trends of modern surveillance and is used to precede events rather than to assess them in retrospect (2003, p. 14). Lyon defines big data as "the capacity to search, aggregate and cross-reference large data sets" (2014, p. 2). Hence, this paper looks at modern surveillance as relying on big data being automated, remote, entailing data sharing and being used to prevent threats.

The most important feature of post-9/11 surveillance to Lyon is the emergence of social sorting. Social sorting systems obtain personal data to classify people according to specific criteria. To Lyon, modern surveillance always entails classification of people into risk categories. Data 
created through digital surveillance needs to be processed, analysed and stored efficiently to be suitable for decision-making. People's data and, thus, people themselves, are put into social categories according to predefined criteria which Lyon perceives as a means of creating and reinforcing long-term social differences (Lyon, 2003). For instance, people put into "undesirable" categories may experience slower travel (2007b, p. 453). Likewise, social sorting affects power relations between governmental institutions and surveilled and among the surveilled themselves. Lyon defines power as having and using the means to control and influence populations (2007b). The exercise of such political power is increasingly organised through sophisticated, integrated surveillance strategies.

Although data categorisation is not a recent phenomenon, social sorting systems are new in the sense that big data practices enable routine and systematic searches of data doubles 3 (Lyon, 2007b, p. 451). Their emergence can be partly explained by an increase in perceived threats and politicians' wish for more effective population control, that is migration monitoring (2003, p.20). However, social classification of human life is nothing extraordinary. State institutions depend on social differentiation, for example to determine who may vote. Social life depends on categorisation to make sense of personal relations. However, social sorting systems rationalise this process.

Lyon's description of social sorting systems can be structured into three overarching indicators: large-scale databases, social classification and resulting social effects. Table 1 summarises these characteristics. Firstly, social sorting gains strength when security arrangements are internationally harmonised and databases are integrated. The international dimension enables a broad scope of surveillance and increases its efficiency. To signal maximum security, policymakers increasingly design interoperable databases (Lyon, 2007a, pp. 162-165).

Social sorting relies on computer codes assigned to each category and the individual's data double (Lyon, 2003, p. 23). Codes represent the determining factor in surveillance systems that results in differences in people's opportunities as they allow or deny access to areas and experiences (p. 13). By assigning a code to each data double, surveillance becomes remote and impersonal.

Classification occurs with the rationale of risk management, the translation of data into risk categories. The target groups usually are firstly mobile citizens and travellers, secondly, asylum seekers and migrants and, thirdly, criminals (Lyon, 2007a, p. 163). Among the most suspicious categories are presumed terrorists and irregular migrants. This distinction and hierarchy of risk categories reflects Foucault's concept of descending individualisation. Groups at the lower end of social hierarchy are surveilled more than the ones at the upper end (Foucault, 1977).

The classical example of tools of social sorting systems are electronic ID cards. Being markers of membership, they assign a nationality to each data double, classify eligible members and exclude non-citizens (Lyon, 2004). What is new about these systems is the reliance on modern technologies. In particular biometrics has made surveillance more concrete and reliable and has fostered its rationalisation and impact (Ball et al., 2012; Marx, 2002).

Secondly, the systems classify for further judgement. They determine who should be the target of special treatment or suspicion (Lyon, 2004). Social sorting systems put the collected data into risk categories. Risk profiles are assigned according to race, gender, ethnic, national or religious criteria (Salter, 2006, p. 179). Such categorisation relies on massive data processing to identify patterns for intelligent filters. Big data practices enable these pattern-seeking processes (Lyon, 2014, p. 3). 
Finally, categorisation has social effects on classified people as the categories allow for discriminatory treatment. They decide on exclusion or inclusion and thereby create or sustain long-term social differences. In this sense, surveillance may have empowering and disempowering effects. The power of big data lies in the use of information to influence populations, order privileges, and predict and control events. Big data surveillance empowers the governmental entity managing the tools while disempowering people put in undesirable categories (p. 44). For them, social sorting impacts the quality of social existence negatively (Benam, 2011, p. 191). Taking the example of border surveillance systems, being put in the category of a legitimate traveller or of an illegitimate migrant affects one's mobility. Such systems thus have a considerable impact on social existence and raise concerns about human rights such as freedom of movement or freedom from suspicion (Lyon, 2007a, pp. 162-163). Social sorting exemplifies how the supposedly neutral concept of big data surveillance can have social and ethical implications.

Table 1 - Operationalisation: characteristics of social sorting (cf. Ball et al., 2012; Lyon, 2003; Lyon, 2004; Lyon, 2007a)

\begin{tabular}{|c|l|}
\hline Database & $\begin{array}{l}\text { - usual occurrence with harmonisation of international security } \\
\text { arrangements } \\
\text { - increased interoperability } \\
\text { - reliance on computer codes: remote and impersonal control } \\
\text { - systems of risk management } \\
\text { - reliance on biometrics }\end{array}$ \\
\hline Classification & $\begin{array}{l}\text { - spelled-out risk categories } \\
\text { - criteria for categories }\end{array}$ \\
\hline Social effects & $\begin{array}{l}\text { - categories allow for discriminatory treatment } \\
\text { - long-term social differences (inclusion, exclusion) }\end{array}$ \\
\hline
\end{tabular}

\section{EU TRANSNATIONAL SURVEILLANCE SYSTEMS: SIS, VIS AND EURODAC}

In recent years, the EU has assigned increasing importance to transnational databases in controlling border movements (Aas, 2011). The Amsterdam Treaty of 1999 established an area of freedom, security and justice with the surveillance systems SIS, VIS and EURODAC constituting central elements (p. 332). The development of these databases is linked to the aspirations of building a Europe without internal border controls as policymakers sought to compensate for loss of control towards third-country nationals (Brouwer, 2008, p. 2). SIS, VIS and EURODAC shall therefore combine the policy objectives of migration and border control. The terrorist attacks in Madrid and London in 2004 and 2005 have triggered an increased link of migration and security in the EU. Since then, emphasis on border controls in the field of migration policy has been reinforced (p. 31). The EU agency for large-scale IT systems eu-LISA operates the databases and connects them closely to one another (European Commission, 2015).

The Schengen Information System (SIS), operational since 1995, is a data-based registration and surveillance system made up of national databases that feed information into the central one in Strasbourg (Broeders, 2007, pp. 79-80). A second-generation system, called SIS II, was introduced in 2006 to create a technically feasible system for an enlarged EU. SIS $\mathrm{II}_{4}$ has become by far the largest EU database (Brouwer, 2008, p. 14). Since its launch, most data in SIS 
concerns third-country nationals being refused entry to Schengen.

Being designed similarly, the Visa Information System (VIS) complements SIS. VIS, introduced in 2008, has a central database that shares its headquarters with SIS and relies on national counterparts. It registers all persons entering Schengen with a visa and aims at facilitating the identification of persons having stayed irregularly after their visa's expiration (Brouwer, 2008, p. 85).

The EUROpean DACtylographic comparison system (EURODAC) was introduced in 2003 to support the implementation of the Dublin Convention on asylum. This convention determined that the responsibility for an asylum claim lies with the member state having received the respective application. To detect and prevent simultaneous application for asylum in several member states, EURODAC collects fingerprints of applicants (Brouwer, 2008, p. 77). Once correspondence with a stored dataset has been found, applicants may be returned to the member state where the first asylum claim was issued.

Since the three systems are closely connected, they exemplify a trend towards interoperability between transnational surveillance systems in the EU (eu-LISA, 2014; Brouwer, 2008). It is particularly their interoperability and thus size of dataset, searchability and use of modern technologies that reflect their big data practices.

\section{SOCIAL SORTING, BORDERS AND POWER}

\subsection{METHODOLOGY}

To answer the question in how far EU surveillance systems exhibit features of social sorting, I conducted a qualitative content analysis of essential documents and regulations of SIS, VIS and EURODAC. Since SIS II, VIS and EURODAC were introduced between 2000 and 2013, this timeframe is taken as reference. I apply the features of social sorting summarised in Table 1 to the cases. To assess the effect of social sorting systems on borders and power relations, I hold a conceptual discussion.

\subsection{POLICY DOCUMENT ANALYSIS: SOCIAL SORTING IN SIS, VIS AND EURODAC}

\subsubsection{The databases}

Social sorting often occurs with the harmonisation of international security arrangements. SIS, VIS and EURODAC are part of the creation of an area of freedom, security and justice and, thus, serve both migration control and security policy (Walters, 2002, p. 568). The analysis finds strong reference to security-related topics. SIS aims at contributing to "a high level of security" within the EU (Council of the EU [Council], 2007, Art. 1.2). Furthermore, harmonisation of provisions relating to migration, asylum and security is one major objective of SIS (European Parliament \& Council of the EU [EP \& Council], 2006, Art. 24.5; p. 5). Similarly, VIS is devised to enhance security within the Schengen area. Although being a migration policy instrument, "VIS data will substantially contribute to the prevention, detection or investigation of terrorist offences" (EP \& Council, 2008, Art. 3.1). EURODAC shows an interesting development in this respect. The regulation of 2000 refers to asylum while the revised regulation of 2013 puts stronger emphasis on international crime (EP \& Council, 2013, p. 2).5

The criterion of interoperability can also be confirmed for all databases. SIS is designed to be fully connected to VIS by 2020 (European Commission, 2016). Already now, a valid ground for a 
visa refusal in VIS is an alert in SIS (EP \& Council, 2008, Art. 12.2(f)). Finally, EURODAC's regulations recommend the consultation of VIS prior to reviewing EURODAC itself (2013, Art. $20(1)$ ). The systems' interoperability enlarges the available dataset for searches which highlight the importance of big data for their functionality.

A further criterion of social sorting systems is the reliance on computer codes. All three systems are based on alphanumerical codes assigned to each file. This enables greater precision in the search for identities (Council, 2007, Art. 22(b); EP \& Council, 2008, Art. 5.1(a); Council, 2000, Art. 11.1). This ability of cross-referencing data doubles is achieved through the use of big data and increases the systems' efficiency.

To determine whether the databases represent risk management systems as stated by Lyon, I examine their purpose. Systems of risk management assign worth and risk to collected data, which in turn enables judgement. The cases fulfil this criterion. SIS uses collected data including names, physical characteristics not subject to change or sex, primarily to issue alerts "for the purpose of refusing entry or stay" (EP \& Council, 2006, p. 5; Michael \& Michael, 2008). VIS shall assist in the identification of expired visas and support decisions on renewal, refusal or shortening of visas and enable decision-making on visa policy (2008, Art. 2). Similarly, EP and Council call EURODAC a "valuable tool" for managing offences related to both security and migration (2013, p. 3). EURODAC bases decision-making on collected fingerprints that are made available to security agencies upon request. To serve the purpose of risk management, big data grants the databases the "power to predict"6 events (Richards \& King, 2014, p. 397).

Finally, the use of biometric data can be identified in all systems. In particular, they make use of fingerprints and biometric photos (EP \& Council, 2006, p. 5; 2008, p. 61; 2013, p. 2).

In conclusion, with respect to technological aspects, SIS, VIS and EURODAC display distinct characteristics of social sorting.

\subsubsection{Classification}

With respect to risk categories, the databases distinguish between citizens and non-citizens. SIS issues alerts on third-country nationals even if they enjoy free movement within the Schengen area (EP \& Council, 2006, Art. 3(d)). Once EU citizenship is acquired, all data on the concerned individual is deleted, which implies that citizens are not considered a risk (Art. 30). VIS distinguishes between tourists and visa holders. It is a spelled-out purpose of VIS to protect travellers (European Commission, 2015). Hence, every case not classified as a tourist or another desirable category is considered a risk category. EURODAC establishes three categories according to differing attributes of "aliens". Being concerned with asylum applications, the system distinguishes between "applicants for international protection", persons "apprehended in connection with the irregular crossing of an external border" and people "found illegally staying" in the EU (EP \& Council, 2013, Chapters II-IV). Thus, different degrees of risk are assigned to regular applicants and irregular migrants.

The criteria for these categories are spelled out less clearly and remain implicit in the legal documents. While for SIS, the SIRENE manual spells out some criteria (European Commission, 2006), VIS' and EURODAC's criteria remain unspecified. In general, the systems file individuals only above the age of 14 . Furthermore, they do not keep record of citizens. VIS differentiates between visa types that are decisive in determining the data categories (2008, Art. 4). EURODAC puts more emphasis on the manner an individual has entered the Schengen area. It differentiates between irregular and regular travel and between asylum applicants, regular aliens and stateless persons (2013, p. 3).7 
Finally, each of the examined systems defines attributes of identification of the individuals. For SIS, these are general characteristics such as sex, origin-related data and place of birth, biometric data or a comment on whether the person is armed or violent (EP \& Council, 2006, Art. 20). Similarly, VIS stores data on the individual's origin, occupation and residence, in addition to biometric and travel-related information (2008, Art. 9). EURODAC stores information on sex, state of origin, the reference number and biometric data gained through fingerprints (2013, Art. 14).

In conclusion, although the categories' characteristics are not formulated precisely, the systems display strong characteristics of classification.

\subsubsection{Social effects of classification}

Assessing the impact of classification exceeds the informational value of this analysis, since, not surprisingly, the documents do not mention possible social implications. Yet, they still allow for some statements about these effects with secondary literature confirming the assumption of a long-term social impact.

The categories enable discriminatory treatment along the lines of the data groups. Decisions concerning the group may have serious social implications. SIS categorises to refuse entry or stay within the Schengen area (EP \& Council, 2006, p. 5). This implies that the categories have an effect on populations' mobility. With SIS and EURODAC being also used as security instruments, the European Police Office Europol and its international counterpart Interpol can be granted access to the systems. Hence, registered persons are at greater risk of being affected by law enforcement and suspicion (2013, Art. 21; Brouwer, 2008, p. 514). Moreover, a hit in EURODAC may result in the deportation of the concerned person to another member state ( $\mathrm{p}$. 3). VIS equally indicates possible social implications since the risk category affects the applicants' prospects of being granted a visa. In addition, VIS information is linked to the profiles of the travel groups or family members of every data double (2008, Art. 8). If an alert is issued on one member of this 'network', other members are automatically controlled too. Thus, an alert affects more than the concerned file. This practice infringes European fundamental rights since it results in surveillance of third parties who did not, for themselves, cause a reason for being surveilled.

It can be assumed that such discriminatory treatment with respect to mobility or freedom from suspicion results in long-term social differences. The systems provide for repetitive control of data doubles since in particular VIS is not only concerned with the decision on visas but also on the expiration of acquired ones (Broeders, 2007, p. 73). SIS and EURODAC keep data on individuals for ten years and VIS for five years from the date of registration onwards. Hence, the systems exert influence for a considerable time.

Although social effects of social sorting can be both positive and negative, the most serious ethical problems arise from negative discrimination of who Bigo (2014) labels "data-banned" populations (p. 219). Being collectively put in undesirable risk categories, they bear the consequences of slow or even no permission to travel (Pötzsch, 2015, p. 109). This is particularly troublesome when considering the systems' tendency to produce "mistaken identities", people that have been falsely assigned a category (Lyon, 2007b, p. 462; Benam, 2011, p. 203). González Fuster and Gutwirth (2012) even go so far as to consider social sorting as the implicit stigmatisation of people on the move (p. 184). Furthermore, such categorical suspicion commonly relies on stereotypical images and narratives. For instance, this practice may result in the suspicion of all members of a nationality to have illegitimate reasons to travel (Salter, 2006, p. 182). On these grounds, social sorting is a problematic practice and occurs without closer 
attention of policymakers to basic rights (Brouwer, 2008).

\subsection{CONCEPTUAL DISCUSSION: THE EMERGENCE OF SOCIO-DIGITAL BORDERS}

SIS, VIS and EURODAC establish a digital infrastructure exceeding the boundaries of nationstates. The analysis has shown that the EU surveillance systems play a crucial role in deciding on in- and outsiders of European societies, a traditional function of territorial border agencies. The question arises how social sorting changes the concept of the border. What does it entail for a borderless Europe that has evolved since the Schengen acquis?

Borders as such are inherent to human behaviour. Social borders order life and reflect the need for sameness and belonging ( $\mathrm{O}^{\prime}$ Dowd, 2002). They strengthen identity and simultaneously perpetuate notions of difference (Newman, 2006, p. 143; Kroneberg, 2014, p. 9). The border as a territorial demarcation was consolidated in 19th century Western Europe, a manifestation that is paradoxically challenged mostly in Europe through Schengen (O'Dowd, 2002, p. 15). Territorial borders traditionally demarcate power over a state's territory against that of another (Kleinschmidt, 2014). They serve to distinguish cultural or political features towards others and enable the assignment of competences and responsibilities. For instance, the inclusive welfare state depends on a territorial definition of who shall contribute and benefit from it (O'Dowd, 2002, p. 15). In this sense, borders are instruments of both exclusion and inclusion.

Concerns about a borderless Europe have led to a rebordering process against non-EU citizens, a phenomenon Rumford (2006) labels "securitised rebordering" (p. 157; Zaiotti, 2011). Surveillance systems are also reaching into society itself. I claim that the main functions of the territorial border are shifting to a new kind of border drawn within society. SIS, VIS and EURODAC enable decisions on people's mobility. Their interoperable network has assumed the crucial border power of deciding on exclusion or inclusion and population control, and thereby relocates the border into society itself. This exclusionary power is the link between borders and big data surveillance. It becomes especially influential when combined.

While SIS, VIS and EURODAC collect data at territorial borders and therefore rely on territoriality, they simultaneously change these borders' nature. Biometrics and big data surveillance enable rebordering along the lines of the systems' social categories. It is no longer only the territorial border agency that decides on who is an in- or outsider but the databases (Pötzsch, 2015). Territorial borders still exert important functions in population control. However, they have become multiplied and extended through integrated social sorting systems.

Interviews that sociologist Bigo (2014) has conducted with employees of EU border agencies manifest this shift away from territorial borders. His interviewees regard physical borders to be of little significance to their work. They consider borders as being "constructed through the data doubles of individuals who left traces [...] concerning their personal information" (p. 217). Distinguishing themselves from traditional border guards, they consider their work as preventive filtering and analytical software management (ibid.).

I argue that, in addition to territorial borders, a new kind of border has emerged which I label socio-digital border. This term brings together the social purpose of classification and rebordering, and their reliance on big data. The social aspect refers to the lines along which borders are drawn such as risk categories or purpose of travel. The digital aspect refers to the methods that facilitate social sorting and discriminatory decision-making, including biometrics and big data surveillance. It also refers to the border's non-visibility representing a contrast to the visible territorial border. 
Other authors have termed this new border differently. Amoore (2006) labels it "biometric border" while Walters (2002) uses the term "biopolitical border". However, although biometrics is important in the rebordering process, it is not biometric data that determines the border but the systems' categories. Furthermore, the term neglects the surveillance systems' digital and coded character. This dehumanised aspect is considered by Pötzsch (2015) who introduces the term "iBorder" and by Broeders (2007) who uses the label "digital borders". However, equal attention must be paid to the social component of the new border that determines the content of the dividing border line. After all, the digital border enables the reproduction of social borders. Big data technologies create social differences and have rendered social sorting and thereby borders more powerful than before their introduction. Therefore, the term "socio-digital border" as a designation of the observed phenomenon is useful as it combines social aspects of securitised bordering with the digital nature of the border.

Surveillance systems have assumed significant bordering functions. The coding of identities and the thereby permanent manifestation of legitimacy have enabled borders to be possibly reproduced everywhere. Authorities have gained exclusionary powers through surveillance techniques relying on big data which contributes to the disempowerment of categorised groups, both with regard to mobility and political rights.

\section{CONCLUSION}

This study shows how social sorting in EU surveillance systems impacts social and political power relations. Through data classification into social categories, border control gains strength and societal influence beyond territorial boundaries. The reliance of SIS, VIS and EURODAC on big data magnifies both efficiency and (dis)empowering effects of surveillance and border control.

SIS, VIS and EURODAC have taken over the decision on societal exclusion and inclusion, a task that is traditionally assigned to territorial borders. Therefore, social sorting systems change the notion of borders and shift crucial functions to socio-digital borders that have emerged along the lines of the social categories. Thereby, social sorting reaches out into society itself and continues to make a difference there. This paper thus exemplifies how power asymmetries are inherent to surveillance systems relying on big data and raises ethical concerns about social sorting. The power of big data strengthens governmental institutions managing information and being empowered to control and predict events such as population movements. Simultaneously, big data surveillance disempowers the people in undesirable categories.

The paper contributes to surveillance and border studies by combining the two research fields and furthers the understanding of effects of big data surveillance on society. Yet, its methodology cannot explain in-depth implications of social sorting on individuals and social groups. To complement this study, sociological and ethnological research about migrants' experiences with socio-digital border control should be conducted.

Surveillance becomes controversial when disempowering discriminately. To reduce collective negative consequences, border agencies should return to the EU's principle of proportionalitys and reconsider which personal information are vital to achieve internal security. Richards and King (2013) call for the development of "big data ethics", fostering a social understanding of the appropriateness of big data analytics (p. 46). Finally, the functioning of the surveillance systems and the definition of categories should be more transparent and more clearly defined for the 
public. This would enable more public debate about social and ethical implications of surveillance and border management. 


\section{REFERENCES}

Aas, K. F. (2011). 'Crimmigrant' bodies and bona fide travelers: Surveillance, citizenship and global governance. Theoretical Criminology, 15(3), 331-346.

Amoore, L. (2006). Biometric borders: Governing mobilities in the war on terror. Political geography, 25(3), 336-351. Retrieved 26 March 2016, from

http://www.antoniocasella.eu/nume/Amoore_20o6.pdf

Ball, K., Haggerty, K., \& Lyon, D. (Eds.) (2012). Routledge Handbook of Surveillance Studies. Abingdon: Routledge.

Benam, Ç. H. (2011). Emergence of a "big brother" in Europe: Border Control and Securitization of Migration. Insight Turkey, 13(3), 191-207. Retrieved 26 March 2016 from

http://file.insightturkey.com/Files/Pdf/insight-turkey_vol_13_no_3_-2011_benam.pdf

Bendrath, R. (2014). Überwachungstechnologien. Aus Politik und Zeitgeschichte, Überwachen, 64(18-19), 20- 25. Retrieved 13 December 2015, from

http://www.bpb.de/apuz/18309o/ueberwachungstechnologien

Bigo, D. (2014). The (in) securitization practices of the three universes of EU border control: Military/Navy-border guards/police-database analysts. Security Dialogue, 45(3), 209-225.

Broeders, D. (2007). The new digital borders of Europe. EU databases and the surveillance of irregular migrants. International sociology, 22(1), 71-92. Retrieved 3 December 2015, from http://www.iss.nl/fileadmin/ASSETS/iss/Documents/Research_and_projects/DRS/Broede rs_article2007.pdf

Brouwer, E. R. (2008). Digital borders and real rights: Effective remedies for third-country nationals in the Schengen Information System. Leiden: Nijhoff.

Council of the European Union. (2000). Council Regulation (EC) No 2725/20oo of 11 December 2000 concerning the establishment of 'EURODAC' for the comparison of fingerprints for the effective application of the Dublin Convention. Official Journal of the European Union, L 316/110, 15.12.2000. Retrieved 5 November 2015, from http://eur-lex.europa.eu/legalcontent/EN/TXT/PDF/?uri=CELEX:3200oR2725\&from=EN

Council of the European Union. (2007). Council Decision 2007/533/JHA of 12 June 2007 on the establishment, operation and use of the second generation Schengen Information System (SIS II). Official Journal of the European Union, L 205/63-84, 7.8.2007. Retrieved 5 November 2015, from http://eurlex.europa.eu/legalcontent/EN/TXT/PDF/?uri=CELEX:32007Do533\&from=EN

eu-LISA. (2014). eu-LISA in Action. IT in the service of a more open and secure Europe. Luxembourg: Publications Office of the European Union. Retrieved 3 March 2016, from http://bookshop.europa.eu/is-bin/INTERSHOP.enfinity/WFS/EU-Bookshop- Site/de_DE//EUR/ViewPublication-Start?PublicationKey=ELo214892

European Commission. (2006). Commission Decision of 22 September 2006 on amending the Sirene Manual. Official Journal of the European Union, L 317/41-80, 16.11.2006. Retrieved 15 April 2016, from http://eur-lex.europa.eu/legal-content/EN/TXT/PDF/?uri=CELEX:32006Do758\&rid=1 
European Commission. (2015). Visa Information System (VIS). Retrieved 29 May 2015, from http://ec.europa.eu/dgs/home-affairs/what-we-do/policies/borders-and-visas/visainformation-system/index_en.htm

European Commission. (2016). Fact Sheet. Smart Borders Package: Questions \& Answers. Retrieved on 15 April 2016, from http://europa.eu/rapid/press-release_MEMO-16-1249_en.htm

European Parliament and Council of the European Union. (2006). Regulation (EC) No 1987/2006 of the European Parliament and of the Council of 20 December 2006 on the establishment, operation and use of the second generation Schengen Information System (SIS II). Official Journal of the European Union, L 381/4- 23, 28.12.2006. Retrieved 5 November 2015, from http://eur-lex.europa.eu/legalcontent/EN/TXT/PDF/?uri=CELEX:32006R1987\&from=EN

European Parliament and Council of the European Union. (2008). Regulation (EC) No 767/2008 of the European Parliament and of the Council of 9 July 2008 concerning the Visa Information System (VIS) and the exchange of data between Member States on short-stay visas (VIS Regulation). Official Journal of the European Union, L 218/60-81, 13.8.2008. Retrieved 5 November 2015, from https://secure.edps.europa.eu/EDPSWEB/webdav/site/mySite/shared/Documents/Supervi sion/VIS/o8-07-09_Regulation_VIS_EN.pdf

European Parliament and Council of the European Union. (2013). Regulation (EU) No 603/2013 of the European Parliament and of the Council of 26 June 2013 on the establishment of 'EURODAC' for the comparison of fingerprints for the effective application of Regulation (EU) No 604/2013 establishing the criteria and mechanisms for determining the Member State responsible for examining an application for international protection lodged in one of the Member States by a third-country national or a stateless person and on requests for the comparison with EURODAC data by Member States' law enforcement authorities and Europol for law enforcement purposes, and amending Regulation (EU) No 1077/2011 establishing a European Agency for the operational management of large-scale IT systems in the area of freedom, security and justice (recast). Official Journal of the European Union, L 180/1-25, 29.6.2013. Retrieved 5 November 2015, from http://eur-lex.europa.eu/legalcontent/EN/TXT/PDF/?uri=CELEX:32013Ro6o3\&from=EN

Foucault, M. (1977). Discipline and Punish: The Birth of the Prison. New York: Vintage Books.

González Fuster, G., \& Gutwirth, S. (2012). When 'Digital Borders' Meet 'Surveilled Geographical Borders': Why the Future of EU Border Management is a Problem. In J. P. Burgess \& S. Gutwirth (Eds.), A Threat Against Europe?: Security, Migration and Integration. Brussels: VUBPRESS.

IOM. (2015). Key Migration Terms. Retrieved 13 June 2015, from https://www.iom.int/keymigration-terms

Jenkins, R. (2012). Identity, surveillance and modernity. In K. Ball, K. Haggerty \& D. Lyon (Eds.), Routledge Handbook of Surveillance Studies. Abingdon: Routledge.

Kleinschmidt, C. (2014). Semantik der Grenze. Aus Politik und Zeitgeschichte, Grenzen, 63(45), 3-8. Retrieved 23 November 2015, from 
http://www.bpb.de/apuz/176297/semantik-der-grenze

Kroneberg, C. (2014). Motive und Folgen sozialer Grenzziehung. Aus Politik und Zeitgeschichte, Grenzen, 63(4-5), 9-14. Retrieved 23 November 2015, from

http://www.bpb.de/apuz/176299/motive-und-folgen-sozialer-grenzziehungen

Lyon, D. (2003) Surveillance as social sorting. Computer codes and mobile bodies. In D. Lyon (Ed.), Surveillance as social sorting. Privacy, risk and digital discrimination (pp. 13-30). New York: Routledge.

Lyon, D. (2004). Identity cards: social sorting by database. Oxford Internet Institute, Internet Issue Brief, 3. Retrieved 13 June 2015, from

http://papers.ssrn.com/sol3/papers.cfm?abstract_id=1325259

Lyon, D. (2007a). Surveillance, security and social sorting emerging research priorities.

International criminal justice review, 17(3), 161-170.

Lyon, D. (2007b). Surveillance, power and everyday life. In R. Mansell, C. Avgerou, D. Quah \& R. Silverstone (Eds.), Oxford Handbook of Information and Communication Technologies (pp. 449-472). Oxford: Oxford University Press. Retrieved 26 March 2016, from https://panoptykon.org/sites/default/files/FeedsEnclosure-oxford_handbook_3.pdf

Lyon, D. (2014). Surveillance, Snowden, and big data: capacities, consequences, critique. Big Data \& Society, 1(2), 1-13. Retrieved 26 March 2016, from

http://bds.sagepub.com/content/1/2/2053951714541861.long

Marx, G. T. (2002). What's New About the "New Surveillance"? Classifying for Change and Continuity. Surveillance and Society, 1(1), 9-29. Retrieved 23 November 2015, from http://library.queensu.ca/ojs/index.php/surveillance-and\%ogsociety/article/viewFile/3391/3354

Michael, K., \& Michael, M. G. (2008). Schengen Information System II: The balance between civil liberties, security and justice. Australia and the New Technologies: Evidence Based Policy in Public Administration Vol. 3. Retrieved 26 March 2016, from

http://works.bepress.com/kmichael/53/

Newman, D. (2006). The lines that continue to separate us: borders in our 'borderless' world. Progress in Human geography, 30(2), 143-161. Retrieved 2 December 2015, from http://iner.udea.edu.co/grupos/GET/Seminario_Geografia_Perla_Zusman/2-newman.pdf

O'Dowd, L. (2002). The Changing Significance of European Borders. Regional \& Federal Studies, 12(4), 13- 36.

Pötzsch, H. (2015). The emergence of iBorder: bordering bodies, networks, and machines. Environment and Planning D: Society and Space, 33(1), 101-118.

Richards, N. M., \& King, J. H. (2013). Three paradoxes of big data. Stanford Law Review Online, 66(41), 41-46. Retrieved 26 March 2016, from

http://www.stanfordlawreview.org/online/privacy-and-big- data/three-paradoxes-big-data

Richards, N. M., \& King, J. H. (2014). Big data ethics. Wake Forest Law Review, 49, 393-432.

Retrieved 26 March 2016, from 
http://pacscenter.stanford.edu/sites/all/files/RIchards\%20and\%2oKing\%20Ethics.pdf

Rumford, C. (2006). Theorizing borders. European Journal of Social Theory, 9(2), 155-169.

Salter, M. B. (2006). The global visa regime and the political technologies of the international self: borders, bodies, biopolitics. Alternatives: Global, Local, Political, 31(2), 167-189.

Walters, W. (2002). Mapping Schengenland: denaturalizing the border. Environment and Planning D, 20(5), 561-580. Retrieved 26 March 2016, from

http://citeseerx.ist.psu.edu/viewdoc/download?doi=10.1.1.461.2908\&rep=rep1\&type=pdf

Weidemann, S. (2014). Freiheit unter Beobachtung? Aus Politik und Zeitgeschichte,

Überwachen, 64(18-19), 3- 8. Retrieved 5 November 2015, from

http://www.bpb.de/apuz/183084/freiheit-unter- beobachtung

Zaiotti, R. (2011). Cultures of Border Control: Schengen and the Evolution of European

Frontiers. Chicago: University of Chicago Press.

\section{FOOTNOTES}

1. Migration refers to any movement of people, either across an international border or within a state (IOM, 2015).

2. 9/11 refers to the terrorist attacks of 9 September 2001 on New York City and Washington D.C..

3. Data doubles are the coded profiles of categorised individuals within the databases.

4. In the following, SIS I and SIS II are referred to as SIS.

5. Following the attacks in Madrid and London in the 2000s, international police agencies have used EURODAC to combat terrorism.

6. Big data predictions of risk empower institutions to identify and categorise individuals without granting this power to citizens (Richards \& King, 2014).

7. Regulation (EU) No 603/2013 specifies information on EURODAC's differentiation of categories.

8. Article 5 TEU stipulates that EU policies should not exceed the treaties' aims. 